\title{
The key characteristics of project-based learning: how teachers implement projects in $\mathrm{K}-12$ science education
}

\author{
Anette Markula and Maija Aksela ${ }^{*}$ (i)
}

\begin{abstract}
The aim of this multiple-case study was to research the key characteristics of project-based learning (PBL) and how teachers implement them within the context of science education. K-12 science teachers and their students' videos, learning diaries and online questionnaire answers about their biology related PBL units, within the theme nature and environment, were analysed using deductive and inductive content analysis ( $n=12$ schools). The studied teachers are actively engaged in PBL as the schools had participated voluntarily in the international StarT programme of LUMA Centre Finland. The results indicate that PBL may specifically promote the use of collaboration, artefacts, technological tools, problem-centredness, and certain scientific practices, such as carrying out research, presenting results, and reflection within science education. However, it appeared that driving questions, learning goals set by students, students' questions, the integrity of the project activities, and using the projects as a means to learn central content, may be more challenging to implement. Furthermore, although scientific practices had a strong role in the projects, it could not be defined how strongly student-led the inquiries were. The study also indicated that students and teachers may pay attention to different aspects of learning that happen through PBL. The results contribute towards a deeper understanding of the possibilities and challenges related to implementation of PBL and using scientific practices in classrooms. Furthermore, the results and the constructed framework of key characteristics can be useful in promoting research-based implementation and design of PBL science education, and in teacher training related to it.
\end{abstract}

Keywords: Key characteristics, Design principles, Project-based learning, Interdisciplinary education, Teachers, Students, Implementation, Science education, Biology education

\section{Introduction}

Project-based learning (PBL) can be a useful approach for promoting twenty-first century learning and skills in future-oriented K-12 science education. PBL refers to problem-oriented and student-centred learning that is organised around projects (Thomas, 2000). This means that the intended learning of new skills and content happens through the project that students carry out in groups (Condliffe et al., 2017; Parker et al., 2013; Thomas 2000). Thus, PBL can be described as a

\footnotetext{
* Correspondence: maija.aksela@helsinki.fi

LUMA Science Helsinki, Faculty of Science, University of Helsinki, Helsinki, Finland
}

collaborative inquiry-based teaching method where students are integrating, applying and constructing their knowledge as they work together to create solutions to complex problems (Guo et al., 2020). It is important that students practice working like this at school, as future generations will need to be able to overcome global enmental problems. As such, science education has to their scien problem-solving and decision-making (Miller \& Krajcik, 2019). 
PBL relies on four significant ideas from learning sciences: learning is most effective when students (1) construct their understanding actively and (2) work collaboratively in (3) authentic learning environments, whilst being sufficiently scaffolded with (4) cognitive tools (Krajcik \& Shin, 2014). Compared to traditional teacher-led instruction, PBL has been found to result in greater academic achievement (Chen \& Yang, 2019; Balemen \& Özer Keskin, 2018). Additionally, it has been shown to improve students' skills in critical thinking and question-posing (Sasson et al., 2018). There is also some evidence that PBL might contribute to developing students' intra- and interpersonal competencies (Kaldi et al., 2011).

Within science and technology education, one of the key benefits of PBL is arguably immersing students in using scientific practices, such as asking questions (Novak \& Krajcik, 2020). Whilst various approaches can be taken to PBL, scientific practices are often considered as one of its key characteristics (see Table 1 for discussion about the key characteristics of PBL). The idea is that in PBL, students should participate in authentic research in which they use and construct their knowledge like scientists would (Novak \& Krajcik, 2020). Using scientific practices has been found to contribute towards students' engagement when learning science (Lavonen et al., 2017), and PBL does indeed appear to have a positive impact on students' attitudes and motivation towards science and technology (Kortam et al., 2018; Hasni et al., 2016). PBL allows students to see and appreciate the connection between scientific practices and the real world, significance of learning, carrying out investigations and the open-endedness of the problems under investigation (Hasni et al., 2016).

Nevertheless, according to the review done by Condliffe et al. (2017), the efficacy of PBL in terms of student outcomes is not entirely clear. In a more recent review, however, Chen \& Yang (2019) found more distinctive benefits to learning compared to previous studies. As they suggest, it may be that implementation of PBL has developed between 2000 and 2010, potentially owing to the better availability of training programmes and materials. Nonetheless, whilst Chen \& Yang (2019) did find that PBL improves students' academic achievement in STEM (science, technology, engineering and mathematics), they also found that the positive effect of PBL appeared to be somewhat bigger in social sciences compared to STEM subjects. Additionally, the various distinctions between different researchers for what makes PBL different from other closely related instructional approaches, such as inquiry-based and problembased learning, make it challenging to confidently determine exactly how effective PBL is as an instructional method (Condliffe et al., 2017).
However, PBL is supported by governments, researchers, and teachers in many countries (Novak \& Krajcik, 2020; Condliffe et al., 2017; Aksela \& Haatainen, 2019; Annetta et al., 2019; Hasni et al., 2016). Studies have found that teachers consider PBL as an approach that promotes both students' and teachers' learning and motivation, collaboration and a sense of community at school level, student-centred learning, connects theory with practice and brings versatility to teachers' instruction (Viro et al., 2020; Aksela \& Haatainen, 2019). However, regardless of teachers' enthusiasm towards PBL, they can still struggle with its implementation (Tamim \& Grant, 2013). PBL is a challenging method to use in practice, as it requires a fundamental understanding of its pedagogical foundations (Han et al., 2015), and it appears that teachers tend to have limited and differing conceptions about PBL (Hasni et al., 2016). For example, PBL is often defined through its distinct characteristics (Hasni et al., 2016; Thomas, 2000), but these tend to be unknown to teachers (Tamim \& Grant, 2013). What is more, research has indicated that in order for PBL to be implemented as it is described by researchers, teachers require training and multiple years of practice with it (Mentzer et al., 2017). In fact, students display greater learning gains when their teacher is experienced with PBL (Capraro et al., 2016; Han et al., 2015), and it appears that partial or incorrect implementation of PBL may even have negative consequences for students' academic performance (Capraro et al., 2016; Erdoğan et al., 2016).

Both Viro et al. (2020) and Aksela \& Haatainen (2019) found that according to STEM teachers, the most challenging aspects of implementing PBL are project organisation (for example, time management), technical issues, resources, student-related challenges and collaboration (Viro et al., 2020; Aksela \& Haatainen, 2019). As PBL requires students to study a certain phenomenon in detail by using scientific practices, it takes longer than more traditional approaches (Novak \& Krajcik, 2020). Researchers have also reported that teachers consider irrelevance to subject teaching and an unfamiliar teaching style among the significant negative aspects of PBL (Viro et al., 2020). Implementation of PBL should focus on teaching twenty-first century skills, being studentcentred, and building strong and personal interaction between students and teachers (Morrison et al., 2020). This requires both teachers and students to take on new roles. In PBL, teachers are often having to act simultaneously as designers, champions, facilitators and managers, and students are expected to be self-directed learners who are able to endure the ambiguity and openendedness of PBL projects (Pan et al., 2020).

Despite the move towards student-centred approaches (for example, inquiry-based teaching) in many national 
Table 1 Framework of the key characteristics of PBL. The six characteristics are as proposed by Krajcik \& Shin (2014)

\section{Characteristic Overview of purpose and features from literature}

1. Driving question - One of the most commonly recognised characteristics of PBL (Miller \& Krajcik, 2019; Condliffe et al., 2017; Mentzer et al., 2017; Hasni et al., 2016; Krajcik \& Shin, 2014; Thomas, 2000; Blumenfeld et al., 1991).

- PBL projects are centred around the driving question: it directs the work, provides the context for it, and reminds the students of the purpose of the various activities included in the project unit (Hasni et al., 2016; Krajcik \& Shin, 2014; HmeloSilver, 2004; Thomas, 2000; Blumenfeld et al., 1991). The driving question creates continuity and cohesion (Mentzer et al., 2017).

- The end product created at the end of the PBL unit will answer the driving question (Blumenfeld et al., 1991).

- The following features characterise a good driving question in STEM PBL (Hasni et al., 2016):

1. The driving question has an authentic link to the real world experienced by the learners and it is interesting to them.

2. The driving question is open-ended and it challenges the learners to carry out intellectually challenging tasks, whilst considering their age and skill set.

3. The driving question creates the need to understand the central scientific concepts related to the studied subject.

2. Learning goals

- PBL should enable students to learn new topics and skills central to the curriculum (Bell, 2010; Tal et al., 2006; Thomas, 2000). As such, PBL should be the primary instructional method in a course, rather than a separate section of it (Condliffe et al., 2017; Parker et al., 2013). For example, Thomas (2000) states that PBL projects should always teach students new skills and content that are central to the curriculum, and as such projects that are used to enrich the curriculum or revise are not PBL. However, Tamim \& Grant (2013) contest this strict view and suggest viewing PBL more broadly, as a continuum.

- PBL tends to consume more time than traditional teacher-centred approaches and as such, it is vital for teachers to feel as though they are able to reach the statutory learning outcomes through it (Krajcik \& Shin, 2014).

- To allow the students to gain a deeper understanding of the topic, ask questions and collaborate, the PBL unit should last for longer than one lesson (Krajcik \& Shin, 2014; Stearns et al., 2012; Thomas, 2000; Blumenfeld et al., 1991). Whilst a consensus around the idea that PBL should extend over a significant time period seems to exist, it is yet to be specified how long exactly the inquiry should be to qualify as PBL (Condliffe et al., 2017). Chen \& Yang (2019) suggest that using PBL for at least two hours per week leads to significantly better academic achievement in students compared to using PBL for less than two hours per week.

3. Scientific practices - In STEM PBL, students should actively use scientific methods in order to solve and study the driving question (Krajcik \& Shin, 2014; Tal et al., 2006; Thomas, 2000; Blumenfeld et al., 1991).

- The PBL unit should allow students to plan and carry out their own research (Mentzer et al., 2017). When developing research questions and methods, students will gain experience in using scientific practices, develop their cognitive skills and build their understanding of the topic (Novak \& Krajcik, 2020; Krajcik \& Shin, 2014; Thomas, 2000; Blumenfeld et al., 1991).

- Whilst a teacher may choose the driving question, students need to be given the possibility to study their own questions within the scope of the driving question (Krajcik, 2015), as presenting questions is an integral part of scientific research (Chin \& Osborne, 2008).

- The scientific practices identified from inquiry-based learning research can be used to describe these practices as found in PBL. Students engage in the following scientific practices within a research project (Pedaste et al., 2015):

1. Orientation into the topic: at the end, students have a problem that they need to solve.

2. Conceptualisation:

a. Presenting research questions

b. Presenting hypotheses

3. Investigation:

a. Exploration (if there is only a research question but no hypothesis)

b. Experimentation (if there is a hypothesis)

c. Data interpretation.

4. Conclusions: students draw them based on the collected data.

5. Discussion:

a. Communicating the results

b. Reflection

4. Collaboration $\quad$ - During PBL, students carry out research in collaboration with each other (Krajcik \& Shin, 2014; Tal et al., 2006).

- Ideally, PBL includes collaboration with experts, companies or parents (Krajcik, 2015; Tal et al., 2006).

- Collaboration is motivating for students (Malone \& Lepper, 1987), and it models a scientist's way of working and allows students to develop their communication skills (Bestelmeyer et al., 2015), and to practice dividing responsibilities and roles (Blumenfeld et al., 1991).

- However, collaboration should be seen as a means to reach the primary goals of PBL; practising science, understanding central concepts, and learning how scientific knowledge is created and used (Hasni et al., 2016).

5. Using technological - Science education should model the importance of computer aided technology in modern scientific research (Edelson, tools 2001)

- Technology can support student learning through, for example, increased interest, modelling concepts, and strategic support (Tal et al., 2006; Blumenfeld et al., 1991), and it allows the learners to preserve and present knowledge more widely (Edelson, 2001). Learning technologies constitute an important scaffold to students to manage the project activities (Krajcik \& Shin, 2014).

- Technology can also support teachers: it can be used to give instructions and support the projects (Blumenfeld et al., 1991).

- Technology can be used to create the artefacts (Tal et al., 2006).

- However, similarly to collaboration, using technology in the PBL unit should in most cases be seen more as a tool rather 
Table 1 Framework of the key characteristics of PBL. The six characteristics are as proposed by Krajcik \& Shin (2014) (Continued)

\begin{tabular}{|c|c|}
\hline Characteristic & Overview of purpose and features from literature \\
\hline & $\begin{array}{l}\text { than the primary goal (Hasni et al., 2016). Whilst technology is useful in PBL and using information technologies appears to } \\
\text { improve students' academic achievement in PBL, it does not necessarily need to be the focal point (Chen \& Yang, 2019). }\end{array}$ \\
\hline 6. Creating an artefact & $\begin{array}{l}\text { - In PBL, the learning process is centred around producing an artefact or an end product that answers the driving question } \\
\text { (Krajcik \& Shin, 2014; Tal et al., 2006; Blumenfeld et al., 1991). } \\
\text { - Artefacts have been proposed to be what differentiates PBL from problem-based and inquiry-based learning (Hasni et al., } \\
\text { 2016; Sahin, 2013). } \\
\text { - Artefacts present the students' cognitive work and their level of understanding (Novak \& Krajcik, 2020; Blumenfeld et al., } \\
\text { 1991). They are concrete, for example, games, posters, models, plays, websites or drawings (Krajcik \& Shin, 2014; Blumenfeld } \\
\text { et al., 1991). } \\
\text { - The artefact should (Krajcik \& Shin, 2014): } \\
\text { 1. Answer the driving question. } \\
\text { 2. Reveal the students' level of understanding. } \\
\text { 3. Support students to gain an understanding about the topic when they are creating the artefact. } \\
\text { - The PBL unit could lead to multiple artefacts, but they should culminate into one artefact that answers the driving } \\
\text { - question (Blumenfeld et al., 1991). } \\
\text { - Creating artefacts is beneficial for learning: students can be expected to learn more effectively when they create external } \\
\text { representations of their conceptions (Krajcik \& Shin, 2014). Deploying physical objects in the learning process also expands } \\
\text { the limitations set by working memory (National Academy of Engineering and National Research Council, 2014). Creating } \\
\text { artefacts forces the students to rebuild their understanding constantly (Krajcik \& Shin, 2014). } \\
\text { - Ideally, the artefacts should be made public and presented to an audience (Condliffe et al., 2017). } \\
\text { - However, within science education there is a need to conceptualise artefacts better; articles tend to not specify why } \\
\text { certain artefacts are specific to PBL, and the artefacts rarely serve a real purpose, which disregards the overarching goal of } \\
\text { striving towards authenticity in PBL (Hasni et al., 2016). PBL artefacts should be meaningful (Novak \& Krajcik, 2020). }\end{array}$ \\
\hline
\end{tabular}

curricula, such as in the United States (National Research Council, 2012), Finland (Lähdemäki, 2019) and throughout much of Europe (European Commission, 2007), there is a distinct lack of research about PBL that is initiated by teachers (Condliffe et al., 2017). There is very little research into how teachers understand and use PBL when they are not guided by university researchers, and the models they develop for its implementation (Hasni et al., 2016). It is also important to research what kinds of changes teachers make to PBL curricula to adapt them to their classes, and how this process could be supported (Condliffe et al., 2017). Often the reality in classrooms differs from the visions in curricula (Abd-El-Khalick et al., 2004), and simply reforming the science curricula does not mean that teachers understand how to implement the new concepts into their teaching (Severance \& Krajcik, 2018). In order to gain a better understanding of how teachers implement $\mathrm{PBL}$ and the related possibilities and challenges in practice, and to promote the use of PBL in education, PBL units from $\mathrm{K}-12$ schools were studied from the perspective of key characteristics of PBL. The studied schools were from several different countries and they all had participated in the international StarT programme (https://start.luma.fi/en/) by LUMA Centre Finland (see 'Participants').

\section{Key characteristics of PBL}

Most projects done at schools are not considered to be PBL, as PBL is often defined more specifically through its distinct characteristics (Hasni et al., 2016; Thomas, 2000), also referred to as 'design principles'
(Condliffe et al., 2017). However, there is still ambiguity among researchers about what the exact key characteristics or design principles of PBL are (Condliffe et al., 2017; Hasni et al., 2016). Krajcik \& Shin (2014) propose the following six features as key characteristics of PBL: (1) driving question, (2) learning goals, (3) scientific practices, (4) collaboration, (5) using technological tools, and (6) creating an artefact. These characteristics, including their purpose and features, have been discussed based on the literature review in Table 1.

In this study, the PBL units were researched by using the six key characteristics found in Table 1 as a framework (Krajcik \& Shin, 2014). The categories in the content analysis (see Table 2 in 'Methods') were based on these characteristics. At the time of doing the analysis, the model proposed by Krajcik \& Shin (2014) was the most recent and detailed description of the characteristics of PBL that allowed study into the quality of the PBL units in practice. Additionally, their framework is in line with the views of other authors who focused on the characteristics of PBL, including the recent systematic review by Hasni et al. (2016) into the characteristics of STEM PBL used by researchers, and with the reviews done by for example, Condliffe et al. (2017) and Thomas (2000). However, in order to study the quality of PBL units under each of the characteristics, the framework was developed further by using the most current literature. For example, the phases of inquiry-based learning (Pedaste et al., 2015) were used to study how scientific practices were carried out by the schools.

Most earlier science education studies have looked at teachers' perceptions of PBL through questionnaires and 
Table 2 The chosen framework for content analysis

\begin{tabular}{|c|c|c|}
\hline Characteristic & Categories used in the analysis & Rationale for the categories \\
\hline $\begin{array}{l}\text { 1. Driving } \\
\text { question }\end{array}$ & $\begin{array}{l}\text { - Features of a good driving question in STEM PBL } \\
\text { (Hasni et al., 2016): } \\
\text { 1. The driving question has an authentic link to the } \\
\text { real world experienced by the learners. } \\
\text { a. Learning environments are local or otherwise } \\
\text { familiar to students. } \\
\text { b. Use of socio-scientific issues. } \\
\text { 2. The driving question is open-ended. }\end{array}$ & $\begin{array}{l}\text { - Authenticity can also be demonstrated by having students participate in } \\
\text { using scientific practices (Hasni et al., 2016). However, this was studied } \\
\text { under '3. Scientific practices'. Additionally, due to the level of detail in the } \\
\text { studied materials, 'familiar or local learning environments' were } \\
\text { considered in the wider sense of the term. } \\
\text { - The third feature of a good driving question, "The driving question } \\
\text { creates the need to understand the central scientific concepts related to } \\
\text { the studied subject" (Hasni et al., 2016), was not included. This was due to } \\
\text { the studied projects being from different countries, and examining the } \\
\text { projects in relation to the different curricula would have been out of the } \\
\text { scope of this study. }\end{array}$ \\
\hline $\begin{array}{l}\text { 2. Learning } \\
\text { goals }\end{array}$ & $\begin{array}{l}\text { - Learning goals stated by students and teachers: } \\
\text { a. Practical goals } \\
\text { b. Goals with a reference to students' development } \\
\text { - Learning gains stated by students and teachers }\end{array}$ & $\begin{array}{l}\text { - Since the international sample of the study did not allow a direct } \\
\text { comparison between the projects and the national curricula, the two } \\
\text { main aspects of this key characteristic were chosen as the focus: did the } \\
\text { teachers or students report any learning goals that were set for the } \\
\text { project, and did they report any learning that happened as a result of the } \\
\text { project? }\end{array}$ \\
\hline $\begin{array}{l}\text { 3. Scientific } \\
\text { practices }\end{array}$ & $\begin{array}{l}\text { 1. Conceptualisation: } \\
\text { a. presenting research questions } \\
\text { b. presenting hypotheses } \\
\text { 2. Investigation: } \\
\text { a. exploration (if there is only a research question but } \\
\text { no hypothesis) } \\
\text { b. experimentation (if there is a hypothesis) } \\
\text { c. data interpretation. } \\
\text { 3. Conclusions. } \\
\text { 4. Discussion: } \\
\text { a. communicating the results } \\
\text { b. reflection }\end{array}$ & $\begin{array}{l}\text { - Scientific practices were studied through the phases of inquiry-based } \\
\text { learning, as they describe the scientific practices that students carry out in } \\
\text { practice within one research project (Pedaste et al., 2015). } \\
\text { - First phase, 'orientation', was left out as its outcome, the driving question, } \\
\text { is studied separately. } \\
\text { - Many models developed for evaluating the quality of inquiry-based learn- } \\
\text { ing can be adapted for PBL (Thys et al., 2016). Also, for example, Mentzer } \\
\text { et al. (2017) studied how teachers implemented the phases of inquiry- } \\
\text { based learning in their PBL unit plans. }\end{array}$ \\
\hline 4. Collaboration & $\begin{array}{l}\text { - Collaboration between students } \\
\text { - Collaboration between teachers } \\
\text { - Collaboration with partners from outside of the } \\
\text { school }\end{array}$ & - These categories arose from the materials. \\
\hline $\begin{array}{l}\text { 5. Using } \\
\text { technological } \\
\text { tools }\end{array}$ & $\begin{array}{l}\text { - ICT (information and communication technologies). } \\
\text { - Technology that was used as a scientific research } \\
\text { tool. }\end{array}$ & - These categories arose from the materials. \\
\hline $\begin{array}{l}\text { 6. Creating an } \\
\text { artefact }\end{array}$ & $\begin{array}{l}\text { - The same question/problem is answered to with } \\
\text { multiple artefacts. } \\
\text { - Multiple single artefacts from separate activities. } \\
\text { - One clear artefact. } \\
\text { - A larger artefact that includes the smaller ones. }\end{array}$ & $\begin{array}{l}\text { - These categories arose from the materials. } \\
\text { - Krajcik \& Shin (2014) outline that the artefact should answer the driving } \\
\text { question, reveal the students' level of understanding, and support } \\
\text { students in gaining an understanding about the topic. These would have } \\
\text { been useful categories, however it was not possible to use them in this } \\
\text { study due to the lack of driving questions and detail about the aims of } \\
\text { the projects. }\end{array}$ \\
\hline
\end{tabular}

interviews (Hasni et al., 2016), but this study analysed teachers and students' reports of their projects in practice. Considering the widely recognised challenges in the implementation of $\mathrm{PBL}$, and the shift in many national curricula towards PBL and similar approaches, there is an urgent need to understand how teachers are managing the change, and what kinds of models they are developing for the implementation of the new curricula in their classrooms. The aim of this study is to understand possibilities and challenges related to the implementation of PBL in practice through the key characteristics (Table 1). The detailed research questions are: (1) Which key characteristics of PBL do teachers implement in the projects? and (2) How do teachers implement these characteristics in practice?

\section{Methods}

This study was carried out as a multiple-case study (Yin, 2014) on schools that participated in the international StarT programme by LUMA Centre Finland from different countries. A multiple case study allows for comparison between the differences and similarities between the cases (Yin, 2014), and therefore to gain a preliminary idea of characteristics or issues that might be common across the schools. The PBL units of twelve K-12 schools were studied (see 'Participants' for further details on the selection criteria). The schools participated in the international StarT competition organised by LUMA Centre Finland (https://start.luma.fi/en/) during the academic year of $2016-17$ or $2017-18$. 


\section{The StarT programme}

StarT encourages teachers to share their best models for implementing PBL, and students to present the products and research they have done within their groups (StarT programme). The competition has two categories: teachers' descriptions of the PBL units that were carried out by the schools ('best practices'), and 'students' projects' that describe what individual student groups studied, created and learned during the school's PBL unit. Each school was able to upload one entry to the teachers' category, describing the implementation of the project unit from teachers' perspective as a best practice for other schools, and an unlimited number of students' projects related to this unit. As such, each 'student project' is part of the same PBL unit organised by the school, but it describes what one student group produced under the PBL unit implemented by the teachers. Depending on the school and how much freedom the students had in the PBL unit, the student groups might have had completely different research topics, or they might have just produced slightly different artefacts to the same problem.

To participate in each category, the schools needed to upload a three-minute-long video describing the best practice or the project and to answer questions on an online form. Additionally, student groups were required to upload a learning diary, the format of which could be freely chosen. As such, the schools had significant freedom in terms of what they wanted to report about their PBL units. At the time of the data collection, the participants did not receive any professional development training from StarT, but depending on how closely they followed the online channels of StarT, they had access to project ideas and videos from other participants via the programme website, and the programme also included voluntary webinars and newsletters. However, these materials were freely available to anyone on the internet, and participating in the competition did not require any other engagement with the StarT programme.

\section{Content analysis}

Deductive content analysis is suitable for research that aims to study an existing model or theory (Hsieh \&
Shannon, 2005). The key characteristics of PBL shown in Table 1 were used as a basis for the deductive and inductive content analysis, where it was determined which characteristics teachers implemented in the projects, and how they did this. In qualitative content analysis, data is analysed by reducing it to concepts that describe the studied phenomenon, for example, through pre-defined categories, whilst also acknowledging the themes rising from the data (Elo et al., 2014; Cohen et al., 2007). The final categories used in the deductive analysis, and discussion about decisions regarding them, can be seen in Table 2. The data was looked at inductively within these categories (Marshall \& Rossman, 2014). An example of the coding combining inductive and deductive content analysis is given in Table 3.

The analysed materials ( $n=12$ project units and $n=17$ students' projects; see details under 'Participants' and in Table 5) were written responses to questions on an online form, videos and learning diaries. The units considered in the analysis were words, sentences, and paragraphs from verbal communication. As the students' projects were what individual student groups produced within the PBL unit of the school, all of the materials provided by an individual school were considered as an entity when studying how the school carried out PBL. Therefore, there was no differentiation between the source of the information (for example, learning diary or best practice video) but instead all materials from a single school were treated as equal evidence of how the characteristics of PBL were implemented (see Table 3). However, since two schools provided multiple student groups' works as student projects, and there were differences in the approaches that different student groups took to carrying out their project work, also the number of student projects displaying each of the key characteristics is included in Table 6 under 'Results'.

In order to see how the six key characteristics of PBL were distributed across the projects, the overall frequencies of characteristics displayed in a project unit $(1=$ present, $0=$ not present) were counted. Table 4 displays the sections from the coding framework that were included in the frequency count. Each row in the second column was counted as ' 1 ' if it was observed and as ' 0 ' if

Table 3 An example of the coding combining inductive and deductive content analysis

\begin{tabular}{|c|c|c|c|c|}
\hline \multicolumn{5}{|c|}{ Studied characteristic: The driving question and its topic } \\
\hline School & Original expression & Simplified expression & Sub-category & Main category \\
\hline \multirow[t]{2}{*}{$\begin{array}{l}\text { Project } \\
\mathrm{X}\end{array}$} & $\begin{array}{l}\text { "The goal of our work is to use and apply renewable } \\
\text { energy sources. }\end{array}$ & Applying renewable energy sources & $\begin{array}{l}\text { Ecological energy } \\
\text { consumption }\end{array}$ & $\begin{array}{l}\text { Environmental } \\
\text { problems and } \\
\text { climate change }\end{array}$ \\
\hline & $\begin{array}{l}\text { "Impressions were more than excellent, as we achieved } \\
\text { exactly what we wanted: to get people interested and to } \\
\text { raise awareness of energy efficiency, renewable energy } \\
\text { sources and in general about the preservation of our } \\
\text { planet. }\end{array}$ & $\begin{array}{l}\text { Raising awareness about energy } \\
\text { efficiency, renewable energy } \\
\text { sources and being ecological }\end{array}$ & $\begin{array}{l}\text { Raising awareness of the } \\
\text { environmental effects of } \\
\text { energy production }\end{array}$ & $\begin{array}{l}\text { Raising } \\
\text { awareness }\end{array}$ \\
\hline
\end{tabular}


Table 4 Features used to study the distribution of the frequencies of PBL characteristics

\begin{tabular}{|c|c|}
\hline Key characteristic & Features used for the frequency count ( $n=24$; feature observed $=1$, feature not observed $=0$ ). \\
\hline \multirow[t]{3}{*}{ Driving question } & Is the project problem-based? \\
\hline & Are the learning environments local? \\
\hline & Does the project deal with socio-scientific issues? \\
\hline \multirow[t]{6}{*}{ Learning goals } & Does the project include learning goals set by the teacher? \\
\hline & Does the project include learning goals set by the students? \\
\hline & Does the project include learning goals related to biology? \\
\hline & Do students describe learning gains? \\
\hline & Do teachers describe learning gains? \\
\hline & Are learning gains related to biology described? \\
\hline \multirow[t]{8}{*}{ Scientific practice } & Do the students ask questions? \\
\hline & Do the students present hypotheses? \\
\hline & Do the students carry out explorations? \\
\hline & Do the students carry out experiments? \\
\hline & Do the students interpret the data? \\
\hline & Do the students draw conclusions from the results? \\
\hline & Do the students present their work to others? \\
\hline & Do the students reflect on doing the project? \\
\hline \multirow[t]{3}{*}{ Collaboration } & Do the students collaborate with each other during the project? \\
\hline & Do the teachers collaborate with each other during the project? \\
\hline & Does the project include collaboration with outside partners? \\
\hline \multirow[t]{2}{*}{ Technology } & Does the project describe using ICT? \\
\hline & Does the project include using scientific technology? \\
\hline \multirow[t]{2}{*}{ Artefact } & Does the project have an artefact? \\
\hline & Does the artefact draw the project together? \\
\hline
\end{tabular}

\section{Frequency of PBL characteristics demonstrated by the schools}

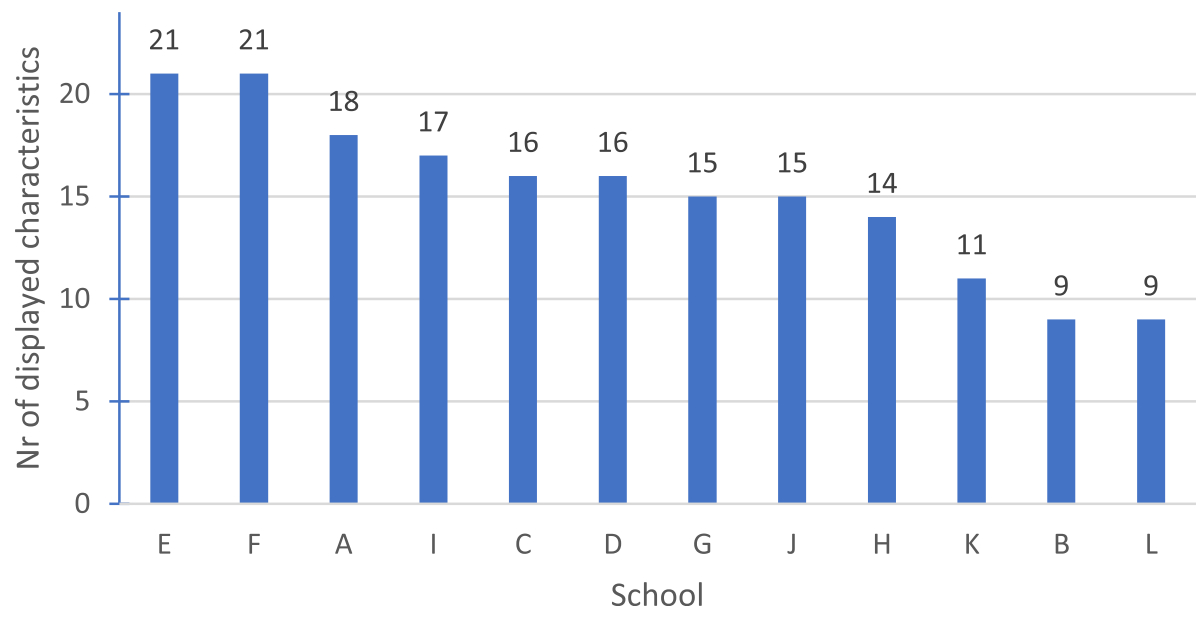

Fig. 1 Frequency of the PBL characteristics demonstrated by the schools A-L ( $n=12$, see Tables 4 and 5$)$ 
it was not. Including these features in the frequency count allows a satisfactory picture of the distribution of the key characteristics across the studied schools to be drawn (See Fig. 1 and Table 6). Scientific practices are emphasised in the count due to their many subcategories, but this was deemed appropriate since they are a good indication of how inquiry-based and student-led the projects were. Learning goals and gains have a significant role too, but their role is similarly justified by their importance - they determine largely whether the projects have resulted in their intended purpose, learning. The results regarding the implementation and distribution of the key characteristics can be found under 'Results'.

In order to improve the reliability and validity of the study, triangulation was employed (Turner et al., 2017) through the use of different types of materials as sources of information. This increases the reliability of studies looking at human behaviour (Cohen et al., 2007) and case studies (Yin, 2014), as that allows cues from different sources to be combined into a more representative image of a case (Baxter \& Jack, 2008). Firstly, the materials consisted of three different types of media: written descriptions and answers to questions on an online form, videos, and a learning diary, the medium of which was not pre-defined for the participants. Secondly, the studied schools only consisted of learning communities that had participated in both the teacher category of StarT with a 'best practice' (a description of the PBL unit from teachers' point of view) and the student category with at least one 'student project' (description of the

Table 5 Distribution of data across school levels. Schools that provided multiple projects: named with subsequent numbers

\begin{tabular}{lll}
\hline School & Project & School level \\
\hline A & A1 & Lower secondary (13-15 y.o.) \\
B & B1 & Lower secondary (13-15 y.o.) \\
B2 & B3 & \\
C & C1 & Upper secondary (16-18 y.o.) \\
& C2 & \\
& C3 & \\
D & C4 & Primary (7-12 y.o.) \\
E & D1 & Primary (7-12 y.o.) \\
F & E1 & Lower secondary (13-15 y.o.) \\
G & F1 & Lower secondary (13-15 y.o.) \\
H & G1 & Primary (7-12 y.o.) \\
I & H1 & Primary (7-12 y.o.) \\
J & I1 & Primary (7-12 y.o.) \\
K & J1 & Primary and lower secondary (7-15 y.o.) \\
L & K1 & Lower secondary (13-15 y.o.) \\
\hline
\end{tabular}

work one student group did during the PBL unit). As such, this study includes the viewpoints of both teachers and students. Additionally, the results from coding were agreed upon by both of the authors.

\section{Participants}

The study analysed students' projects and teachers' best educational practices at K-12 school level $(n=12$ project units and $n=17$ students' projects; see Table 5 for details) that were implemented in 2016-2017 or 20172018. The projects were mostly $(n=9)$ created and implemented by teachers and students, and as such they reflect the reality of schools when it comes to implementing PBL. Only $n=3$ schools mentioned that they had participated in a (university-led) development programme. As such, the studied PBL units provide a plausible reflection of the reality of active teachers implementing PBL (see 'Limitations' for further discussion).

The studied PBL units within the theme 'Nature and environment' were chosen from the learning communities that participated in the international StarT programme in 2016-2017 and in 2017-2018. The other themes that the StarT participants could choose for their projects were 'Technology around us', 'Mathematics around us', 'This works! A mobile toy', 'Stars and space', 'Well-being', 'Home, culture and internationality'. 'Nature and environment' was the most popular single theme during both years of data collection: $n=132$ learning communities from all $n=277$ learning communities indicated that they had done a project related to it in 2016-2017, and $n=50$ out of $n=229$ in 2017-2018. Whilst the studied projects focus on the theme 'nature and environment' in the context of biology education, the interdisciplinary nature of the theme makes the results largely applicable for other sciences. The decision to base the study on a single discipline was made in order to gain a more detailed understanding of the implications of STEM PBL for subject teaching; the case in this study focusing on teaching biology through PBL.

The first criteria in selecting the cases for this study was to include only PBL units implemented by K-12 school (ages 7 to 18). Additionally, only projects themed 'Nature and environment', where biology had a clear role, were included. Finally, only schools that had provided full sets of materials used in the analysis (written responses, videos and learning diaries) were included. Full sets of materials were required for both teachers' descriptions of the PBL unit and students' projects, either in English or Finnish (one school had to be excluded due to an insufficient level of English).

Table 5 presents participants and their school levels: 12 schools matched the criteria described above. In total, 12 project units and 17 students' projects were analysed, 
with only two of the schools having provided more than one student project as a part of the project unit. 11 of the studied schools were from six different countries in Europe, and one school was from Southwest Asia. Schools D, E and F (Table 5) participated in the same PBL development programme implemented by a local university.

The participants gave permission for using their materials for research purposes upon their participation in StarT. However, as this study looks at the projects from an evaluative perspective, direct quotations or detailed descriptions of individual cases that could be used to identify the schools were not included.

\section{Results}

The results for each of the research questions (see end of the chapter "Key characteristics of PBL") will be presented separately.

\section{(1) The key characteristics of PBL in the projects}

The most frequently displayed key characteristics of PBL were collaboration, artefacts, technology, problemcentredness, and out of scientific practices, carrying out research, presenting results and reflection (see Table 6 for more detail). At least some form of collaboration (either between the students, between teachers or with outside partners) took place in all but one of the schools. Any interaction that the schools described as having taken place between different actors was considered as collaboration. Furthermore, technology was used as a part of the projects in all of the schools. Artefacts were also created in all of the studied projects. The results for each of the characteristics are summarised in Table 6 (research question 1), which also outlines how they were implemented (research question 2). As $n=2$ schools provided multiple projects by different student groups, the number of projects $(n=17)$ is higher than the number of schools $(n=12)$.

Regarding scientific practices that students participated in, presenting results $(\mathrm{n}=12$ schools), interpreting results $(n=11)$ and reflection $(n=10)$ were most commonly demonstrated. However, not all schools $(n=4)$ displayed clearly that students had done any research (such as searching for information, observation and collecting data). As testing hypotheses was not visible in any of the projects $(n=0)$, according to the definition of Pedaste et al. (2015), the research was considered as" exploration" $(n=8)$ instead of" experimentation" $(\mathrm{n}=0)$. Only $n=4$ schools included a mention of students having presented questions that had an impact on the course of the project or the investigations that were carried out.

Driving questions and learning goals were among the key characteristics that were not described well (Table
6). None of the twelve schools that were studied displayed evidence of having used a driving question in their projects. However, the majority of the schools $(\mathrm{n}=$ 8) did centre their projects around solving a single problem. According to PBL literature, this is not the same as having a driving question (see Table 1 for a more detailed description), but in the absence of driving questions it was considered useful to study whether the projects were at least centred around solving a single problem. Learning goals (goals with a reference to students' development) were also not that commonly described; materials from $n=6$ schools displayed learning goals set by teachers, but none of the schools displayed learning goals set by students. However, students did appear to set practical goals (goals with no reference to students' development) in the projects from $n=3$ schools, and teachers mentioned these in most schools too $(n=9)$. Furthermore, students' descriptions of what they had learnt as a result of the projects were visible in the materials of $n=10$ schools, whereas teachers' comments regarding that were only visible in those of half $(n=6)$ of the schools.

Figure 1 displays the distribution of the characteristics across the project units. The highest frequency values were for the schools E and F, which both had participated in the same development programme organised by a local university. However, although they did not receive help from researchers, schools $A(f=18), I(f=17)$ and $C(f=16)$ still displayed a reasonably high count of PBL characteristics. In fact, school $\mathrm{C}$ had the same frequency of PBL characteristics as school D, which was the third school to participate in the university-led development programme. Figure 1 shows that there is a clear difference between schools whose PBL units were most closely in line with the PBL framework used in this study ( $\mathrm{f}=21, n=2)$ and the schools that provided project units with the least resemblance to it $(f=9, n=2)$.

\section{(2) Implementation of the key characteristics in the projects}

The main results regarding the implementation of the key characteristics are summarised in Table 6, together with their visibility. The detailed description about the implementation of each of the key characteristics of PBL can be found below: (1) driving question, (2) learning goals, (3) scientific practices, (4) collaboration, (5) using technological tools, and (6) creating an artefact.

Using central problems instead of driving questions did not stop schools from accomplishing some of the characteristics of a good driving question. In all of the schools where the project had a central problem, the problems were related to environmental issues, which meant that they were regarded as socio-scientific issues (Sadler, 2009). All of these schools also used local or 
Table 6 Visibility of key characteristics and their implementation in practice in the PBL units

\begin{tabular}{|c|c|c|c|c|}
\hline Characteristic & & $\begin{array}{l}N=17 \\
\text { projects }\end{array}$ & $\begin{array}{l}N=12 \\
\text { schools }\end{array}$ & Details and examples of implementation \\
\hline \multirow[t]{4}{*}{ 1: Driving question } & $\begin{array}{l}\text { Project has a driving } \\
\text { question }\end{array}$ & 0 & 0 & $\begin{array}{l}\text { - No schools mentioned 'driving questions'. } \\
\text { - } N=1 \text { project was technically based around a question," the subject of how } \\
\text { what we do and use affects the environment", but the question is even } \\
\text { referred to as a topic for the unit, rather than an actual solvable question. }\end{array}$ \\
\hline & $\begin{array}{l}\text { Centred around solving a } \\
\text { problem }\end{array}$ & 11 & 8 & $\begin{array}{l}\text { - None of the projects had a direct mention of 'solving a problem' through } \\
\text { the project. } \\
\text { - } N=11 \text { projects had a clear reference to an attempt to solve a situation or } \\
\text { phenomenon through the project. } \\
\text { - The remaining projects ( } n=6 \text {, from } n=4 \text { schools) did not have a single } \\
\text { problem connecting the various activities. }\end{array}$ \\
\hline & Socio-scientific issues & 11 & 8 & $\begin{array}{l}\text { - All central problems were socio-scientific, as they were related to solving } \\
\text { environmental issues (for example, acid rain, waste disposal). }\end{array}$ \\
\hline & $\begin{array}{l}\text { Local or familiar learning } \\
\text { environments }\end{array}$ & 11 & 8 & $\begin{array}{l}\text { - Researching everyday phenomena ( } n=7 \text { projects), using family or peers as } \\
\text { audience }(n=6) \text {, creating an impact on local environment ( }(n=6) \text {, studying } \\
\text { local environment }(n=5) \text {, visiting local attractions ( } n=2) \text { or collaborating } \\
\text { with students' families }(n=2) \text {. } \\
\text { - As the locality of learning environments was used as a proxy for the } \\
\text { authenticity of the driving question (Hasni et al., 2016), only the } 11 \\
\text { problem-centred projects were considered. }\end{array}$ \\
\hline \multirow[t]{6}{*}{ 2: Learning goals } & $\begin{array}{l}\text { Practical goals set by } \\
\text { teachers }\end{array}$ & 9 & 9 & $\begin{array}{l}\text { - Goals with no reference to students' development; for example, "creating } \\
\text { an herb garden". }\end{array}$ \\
\hline & $\begin{array}{l}\text { Learning goals set by } \\
\text { teachers }\end{array}$ & 6 & 6 & $\begin{array}{l}\text { - Goals that included a reference to the students' development: learning } \\
\text { related to biology ( } n=5 \text { schools), scientific practices }(n=4) \text {, social skills } \\
(n=3) \text {, other twenty-first century skills }(n=1) \text { and technical skills }(n=1) \text {. } \\
\text { - Learning goals related to biology: values ( } n=5 \text { schools), content }(n=3) \\
\text { and skills }(n=1) \text {. }\end{array}$ \\
\hline & $\begin{array}{l}\text { Practical goals set by } \\
\text { students }\end{array}$ & 5 & 3 & - All related to biology ( $n=5$ projects). \\
\hline & $\begin{array}{l}\text { Learning goals set by } \\
\text { students }\end{array}$ & 0 & 0 & $\cdot-$ \\
\hline & $\begin{array}{l}\text { Learning gains according } \\
\text { to teachers }\end{array}$ & 10 & 6 & $\begin{array}{l}\text { - Learning biology: mentioned by students from } n=7 \text { schools, by teachers } \\
\text { from } n=3 \text { schools. }\end{array}$ \\
\hline & $\begin{array}{l}\text { Learning gains according } \\
\text { to students }\end{array}$ & 11 & 10 & $\begin{array}{l}\text { - Learning social skills: teachers } n=6 \text {, students } n=4 \text {. } \\
\text { - Other twenty-first century skills: teachers } n=2 \text {, students } n=1 \text {. } \\
\text { - Scientific practices: teachers } n=2 \text {, students } n=0 \text {. } \\
\text { - Development of environmental values: students } n=4 \text {, teachers } n=2 \text {. } \\
\text { - ICT skills: students } n=2 \text {, teachers } n=1 \text {. } \\
\text { - Personal development (for example, new perspectives and experiences): } \\
\text { students from } n=2 \text { schools (in } n=3 \text { projects), teachers } n=0 \text {. }\end{array}$ \\
\hline \multirow{8}{*}{$\begin{array}{l}\text { 3: Scientific practices } \\
\text { (Pedaste et al. 2015) }\end{array}$} & Asking questions & 4 & 4 & - Questions that had an impact on the investigations carried out. \\
\hline & Forming hypotheses & 0 & 0 & \multirow{2}{*}{$\begin{array}{l}\text { - } N=0 \text { projects had hypotheses, but } n=8 \text { did experiments that could have } \\
\text { included a hypothesis. However, they were considered as exploration due } \\
\text { to lack of hypotheses (Pedaste et al., 2015). }\end{array}$} \\
\hline & Experimentation & 0 & 0 & \\
\hline & Exploration & 14 & 8 & \multirow{3}{*}{$\begin{array}{l}\text { - Research consisted mostly of searching for information and doing } \\
\text { experiments. }\end{array}$} \\
\hline & Interpreting results & 14 & 11 & \\
\hline & Conclusions & 13 & 11 & \\
\hline & Presenting results & 17 & 12 & $\begin{array}{l}\text { - All projects were presented to others at least through the StarT project } \\
\text { videos. } N=16 \text { projects described additionally for example, presentations } \\
\text { and posters. }\end{array}$ \\
\hline & Reflection & 15 & 10 & - Students' comments reflecting on at least some aspect of the project. \\
\hline \multirow[t]{2}{*}{ 4: Collaboration } & Between students & 16 & 11 & $\begin{array}{l}\text { - Mostly group work }(n=16) \text { or presenting the work for other students ( } n= \\
9 \text { ). }\end{array}$ \\
\hline & Between teachers & 14 & 9 & $\begin{array}{l}\text { - Teachers from the same school ( } n=8 \text { schools) } \\
\text { - Teachers from another school }(n=4) \text {. NB. Three of these schools } \\
\text { participated in the same development programme of a local university, } \\
\text { and this university organised the event where collaboration happened. } \\
\text { - No detailed information of how teachers collaborated with each other and } \\
\text { how teachers of different subjects made collaboration happen. }\end{array}$ \\
\hline
\end{tabular}


Table 6 Visibility of key characteristics and their implementation in practice in the PBL units (Continued)

\begin{tabular}{|c|c|c|c|c|}
\hline Characteristic & & $\begin{array}{l}N=17 \\
\text { projects }\end{array}$ & $\begin{array}{l}N=12 \\
\text { schools }\end{array}$ & Details and examples of implementation \\
\hline & $\begin{array}{l}\text { With actors from outside of } \\
\text { the school }\end{array}$ & 14 & 9 & $\begin{array}{l}\text { - The partners were students' parents }(n=9) \text {, universities }(n=5) \text {, media }(n= \\
\text { 5), museums }(n=5) \text {, municipalities or other public agencies }(n=4) \text {, local } \\
\text { people }(n=3) \text {, other experts }(n=3) \text { and organisations }(n=2) \text {. } \\
\text { - Collaboration with media: local newspaper wrote about students' projects. }\end{array}$ \\
\hline \multirow{3}{*}{$\begin{array}{l}\text { 5: Using } \\
\text { technological tools }\end{array}$} & Technology & 17 & 12 & - All studied projects included at least a video of project work. \\
\hline & $\begin{array}{l}\text { ICT (information and } \\
\text { communication } \\
\text { technologies) }\end{array}$ & 15 & 10 & - Commonly available technology at homes and schools. \\
\hline & Scientific technology & 6 & 6 & - Technology designed for scientific measurements and observations. \\
\hline \multirow[t]{5}{*}{ 6: Artefact } & $\begin{array}{l}\text { Concrete creations made by } \\
\text { students }\end{array}$ & 17 & 12 & - For example, reports, models, lessons and webpages. \\
\hline & $\begin{array}{l}\text { Multiple artefacts answer } \\
\text { the same question }\end{array}$ & 6 & 3 & $\begin{array}{l}\text { - More than one artefact that aim to reach the same goal by approaching it } \\
\text { from different angles. }\end{array}$ \\
\hline & $\begin{array}{l}\text { Multiple unconnected } \\
\text { artefacts from separate } \\
\text { activities }\end{array}$ & 5 & 5 & $\begin{array}{l}\text { - The artefacts were related to the same theme but did not attempt to } \\
\text { address a single problem. }\end{array}$ \\
\hline & One clear artefact & 4 & 3 & $\begin{array}{l}\text { - In two (2) projects the artefact was simple and in the other two (2) it was a } \\
\text { complex technical product that was the result of smaller experiments. }\end{array}$ \\
\hline & $\begin{array}{l}\text { A single larger artefact that } \\
\text { consists of the smaller ones }\end{array}$ & 2 & 2 & $\begin{array}{l}\text { - For example, developing the school garden, a webpage on environmental } \\
\text { issues. }\end{array}$ \\
\hline
\end{tabular}

familiar learning environments, which is another characteristic of a good driving question. For example, they researched everyday phenomena ( $n=7$ projects), used family or peers as audience $(n=6)$, created an impact on the local environment $(n=6)$ or studied it $(n=5)$. Some also visited local attractions $(n=2)$ or collaborated with students' families $(\mathrm{n}=2)$.

Interestingly, teachers and students seemed to report different kinds of learning gains; students focused on learning biology ( $n=7$ schools) more than teachers $(n=$ $3)$, who paid attention to progress in learning social skills $(n=6)$, other twenty-first century skills $(n=2)$ and scientific practices $(n=2)$. Students reported these respectively in $n=4, n=1$ and $n=0$ schools. Furthermore, teachers did not mention students' personal development (for example, new perspectives and experiences), which the students themselves noted in $n=2$ schools. Students also mentioned development of their environmental values more often $(n=4$ compared to teachers in $n=2$ schools). ICT skills were mentioned in $n=2$ schools by students and $n=1$ by teachers.

When words that referred to the students' development (for example, "develop", "apply" or "learn") were used in conjunction with the aims of the project, the goal was interpreted as a learning goal. However, when they were absent, the goal was interpreted as a concrete practical aim (for example, "creating an herb garden"). $N=5$ projects displayed practical goals set by students, all of which were related to biology too. However, none of the goals set by students were learning goals according to the definition described above; they all focused on the practical aims of the work instead. Learning goals set by teachers included learning related to biology $(n=5$ schools), scientific practices $(n=4)$, social skills $(n=3)$, other twenty-first century skills $(n=1)$ and technical skills $(n=1)$. The learning goals related to biology could be divided into values ( $n=5$ schools), content $(n=3)$ and skills $(n=1)$.

The materials of the study did not allow extensive assumptions about what was teachers' and what students' viewpoint, but in terms of learning goals, it was deemed necessary to make a distinction based on the sentence structures. If a continuous part of the text displayed students as implementers and was written in third person (for example, "in this project students are expected to ..." or "their goal is to ..."), the learning was interpreted as having been set by the teacher. However, if a continuous part of the text was presented in first person and the text clearly displayed that "we" referred to students, the part of the text that described learning was interpreted as students' viewpoint to learning.

With regards to different scientific practices, it was not possible to identify how student-led the implementation was due to lack of teachers' and students' comments on this. Hypotheses were not presented in any of the projects, although $n=8$ projects included experiments that could have included a hypothesis. The three projects that did not show any signs of doing research and interpreting data were all from the same school and generally vaguely described; these projects did not show evidence of students drawing conclusions either. As all projects were presented to others at least through the 
video that was shared to StarT, all of them were considered as having presented the results of the project. However, all but one project described having done that in other ways as well, for example, by giving presentations for younger students and parents, and making posters.

Most of the projects were carried out in various learning environments and with a variety of partners. In terms of collaboration, three categories emerged: collaboration between students ( $n=11$ schools), collaboration between teachers $(n=9)$, and collaboration between the school and outside actors $(n=9)$. Collaboration between students was mostly group work ( $n=16$ projects) or presenting the work for other students ( $n=9$ projects). Teachers collaborated mostly with other teachers in the same school ( $n=8$ schools), and in some cases with teachers from another school $(n=4)$; however, $n=3$ of these schools participated in the same development programme of a local university, and this university organised the event where the collaboration happened. The materials did not provide information of how the teachers collaborated with each other or divided tasks. The outside partners were students' parents $(n=9)$, universities $(n=5)$, media $(n=5)$, museums $(n=5)$, municipalities or other public agencies $(n=4)$, local people $(n=3)$, other experts $(n=3)$, and organisations $(n=2)$.

Technology used by students in their projects could be divided into two categories that emerged from the materials: ICT (information and communication technologies) and technology that was used as a scientific research tool. All technology that is commonly available and used at homes (and schools), such as editing videos, programming and text editing, and calculation programmes, was included in the ICT category. Any technology that is not commonly expected to be found at homes but that can be used to do scientific measurements and observations (for example, $\mathrm{pH}$ probes and nitrogen indicators, microscopes and voltage meters) was considered as scientific technology. According to this definition, students used scientific technology in $n=6$ projects and ICT in $n=15$ projects.

The artefacts included for example, reports, slideshows, lessons, webpages and miniature models. Multiple artefacts were created in majority of the projects $(n=14)$. Different categories emerged depending on what the role of these artefacts was in the project. In $n=2$ projects, the artefacts were part of a larger, final artefact. For example, one of the schools developed a webpage on climate change, and the contents of the webpage (for example, campaign videos and articles) were produced by separate student groups. Whilst multiple artefacts were created in many projects, it was more common for them to complement each other, meaning that they dealt with the same topic by answering it from a slightly different angle ( $n=6$ projects). In one of these projects, students had, for example, created both a video and a slide show on the same topic, or both a written report and a physical miniature model.

In the third category, in which multiple artefacts were made, students created artefacts that dealt with the same theme but did not directly attempt to answer the same question $(n=5)$. These artefacts were the result of multiple activities that were separate from each other. For example, in one project, students created weather maps, recorded air pressure, and made art related to weather. Although all of these activities were related to the same theme, they were clearly separate from one another, and they did not aim to solve a common problem. In the rest of the projects $(n=4)$, only one clear artefact was produced. In $n=2$ of these projects, the artefact was relatively simple, and the materials did not give evidence of students having had to carry out significant research or experimentation in order to create it. In the other $n=2$ projects, the artefact was clearly a complex technical product, such as a miniature model of an energyefficient house or an irrigation system for plants. These projects displayed evidence of the students having done smaller experiments to be able to create the final artefact. However, as the results of these experiments were not turned into clear artefacts, these artefacts were considered as separate from the first category ('single artefacts form the final artefact').

\section{Discussion}

The main aim of this study was to understand the possibilities and challenges related to the implementation of key characteristics of PBL. These aims will be discussed in relation to each of the research questions below.

\section{Key characteristics of PBL implemented by the teachers}

This study shows that within the context of K-12 science education, using PBL creates opportunities for the implementation of the following key characteristics (Krajcik \& Shin, 2014): collaboration, artefacts, technology, problem-centredness, and scientific practices (Table 6; carrying out research, presenting results, and reflection). However, it might also be true that these characteristics are generally commonly implemented at schools, or aspects of social constructivism or PBL familiar to teachers. For example, Viro et al. (2020) found that teachers saw development of teamwork skills among the most important characteristics of PBL. However, both Viro et al. (2020) and Aksela \& Haatainen (2019) also found that teachers consider technical issues and collaboration as significant challenges in science PBL; as such, teachers' attention may have been directed to describe the use of these practices in their project reports.

This study indicates that schools might struggle especially with implementing driving questions, using 
students' questions, and having students set their own learning goals (see 'Teachers' implementation of the key characteristics' for further discussion). Notably, the characteristics that were commonly visible in the studied PBL units were also well-aligned with the StarT format that promotes their implementation (StarT programme). As such, there might be potential in encouraging teachers to implement certain characteristics of PBL through a competition and its instructions and assessment criteria. For example, StarT does not mention driving questions, and although $3 / 4$ of the projects were centred around solving a problem, no driving questions were visible. Similar to this study, Haatainen \& Aksela (2021) found that only half of the 12 StarT schools they studied included driving questions in their projects. Driving questions have previously been identified as the most challenging aspect of PBL (Mentzer et al., 2017), but it is likely that the studied teachers were not even familiar with the concept as there were no mentions of this 'hallmark' of PBL. Based on the results, it might be worthwhile to include the framework used in this study more visibly into the StarT programme in order to direct the teachers' attention to the desired characteristics. However, although advocated for by StarT (StarT programme), students' questions were hardly visible at all. Goals set by students were also rare ( $n=3$ schools), and none of them showed signs of learning goals set by students (see next section for further discussion).

\section{Teachers' implementation of the key characteristics}

Artefacts and driving questions would seem to require further instruction. Nearly half of the schools produced single artefacts that resulted from separate activities only linked together through a common theme. Artefacts should, however, answer the driving question and draw the project together (for example, Mentzer et al., 2017). Although there were no driving questions, many of the projects that were centred around solving a problem still managed to demonstrate other characteristics of $\mathrm{PBL}$ and the qualities of a good driving question well (centred around solving a problem, use of socio-scientific issues, and local or familiar learning environments). This is in line with the findings of Morrison et al. (2020), who found that teachers are very aware of the importance of authenticity and working with real-world problems in PBL. However, although the driving question can be replaced with a central problem (Hasni et al., 2016), it has an important role in unifying the activities within a PBL unit (Thomas, 2000). Judging by the artefacts, many of the projects lacked the kind of unity described in literature, especially those with no central problem or one that was defined broadly. Therefore, the observations from this study support the views of Mentzer et al. (2017), Krajcik \& Shin (2014) and Blumenfeld et al.
(1991) on the importance of a driving question on unifying the PBL unit.

As only half of the schools displayed learning goals and many of the projects mentioned that they had been carried outside of regular lesson time, it seemed like most of the projects were not primarily used as a means to learn central concepts. According to Thomas (2000), this is not PBL, but Tamim \& Grant (2013) suggest taking a broader outlook on what is considered PBL. Nevertheless, as collaboration, time and organisation of the projects have previously been found to be among the aspects of PBL that teachers find challenging (Viro et al., 2020; Aksela \& Haatainen, 2019), it is not surprising that teachers would prefer to use PBL outside of regular lesson time and focus on developing students' soft skills, rather than focusing on content acquisition. However, spending sufficient time and covering central content have been identified among the central variables for successful PBL teaching in science education (Tal et al., 2006), in addition to building strong teacher-student relationships (Morrison et al., 2020). This indicates that for PBL to be a truly useful method for teachers, the recent changes in curricula towards less content and covering more skills (Novak \& Krajcik, 2020) need to be sustained, and these changes need to be reflected in the standardised tests too.

The learning goals mentioned by the teachers were well aligned with the learning gains associated with PBL (for example, scientific practices, social skills and other twenty-first century skills, environmental values), but this does not equal working with concepts central to their curricula. Furthermore, for students to benefit from the learning gains associated with PBL, the focus should be on learning rather than doing a project; the teachers' attention should be on what the students can research and find out, instead of focusing on what students can create and do (Lattimer \& Riordan, 2011). Mentzer et al. (2017) found that projects implemented by teachers who had used PBL for no longer than a year did not resemble a coherent research project, and that this changed only after two or three years of PBL implementation. The projects tended to be a collection of lessons that were poorly connected to each other, and that consisted of either highly structured activities that had the same predefined outcome for all students, or of activities in which the main purpose was to research without a clear outcome (Mentzer et al., 2017). Similarly, in this study, the projects were often a collection of separate activities tied together through a common theme. According to Blumenfeld et al. (1991), this could be solved with a good driving question which brings cohesion to the project and ensures that students are working with central concepts and problems. 
Although scientific practices were represented generally well across the studied schools, students' questions were hardly visible, and goals set by students were rare ( $n=3$ schools). As such, it remains unclear how studentled the projects were exactly. For example, Herranen \& Aksela (2019) highlight the importance of training teachers to use students' questions as the basis of classroom inquiries, as this has clear implications for how authentically the inquiry will resemble that of scientists. Teachers might see PBL as student-centred (Aksela \& Haatainen, 2019) and use scientific practices in their projects, but the reality is that they can be employed in a highly teacher-led fashion too (Colley, 2006). Earlier research into StarT projects indicated that the projects varied from having "complete student autonomy" to having "teacher-led activities with little student choice" (Haatainen \& Aksela, 2021).

Furthermore, Severance \& Krajcik (2018) found that even with support from researchers, teachers struggled to understand the idea of using scientific practices in their teaching. Also, teachers themselves consider lack of support for PBL implementation, including teachers' professional skills and motivation, among the most common hindrances to PBL implementation (Viro et al., 2020). In line with this, the $n=3$ schools in this study that received support for the implementation of PBL from a university, all displayed a higher count of PBL characteristics and scientific practices than most of the studied schools (Fig. 1). However, whilst two of them displayed the highest count of characteristics across all cases, one of them had a lower count, closer to the values of schools that did not receive help. This highlights the importance of providing additional support for the schools in terms of the pedagogy of PBL and implementing scientific practices, and the fact that even support from a university does not guarantee researchbased implementation of PBL. Even when teachers implement PBL units designed by researchers, they can adapt the unit significantly when moulding it for their educational context (Condliffe et al., 2017). Depending on the teachers' beliefs, it is likely that all of these adaptations are not beneficial for learning (Condliffe et al., 2017).

Additionally, teachers who intended to teach biology through the projects (5/12 schools) mainly focused on developing students' values towards nature and environment. This can of course be expected as all projects aimed to solve environmental issues, but it should not give a reason to exclude goals related to subject-specific content and skills. Especially, as the data consisted of projects in which biology had a clear role, and the students frequently (7/12 schools) mentioned having learnt biology content. However, the teachers mentioned this in three schools only. The explanation could be that students had a more liberal idea of what constitutes as biology content, or that the teachers had not even attempted to teach core content through the projects, and thus did not pay particular attention to development in that area. Nevertheless, the different views between teachers and students in terms of perceived learning gains may be an interesting point to study in the future.

Overall, it seems like the teachers mainly used PBL for learning soft skills, which is commonly reported about PBL (Guo et al., 2020; Aksela \& Haatainen, 2019). For instance, in a study of PBL in mathematics, Viro et al. (2020) found that less than half of the in- and preservice teachers they surveyed $(n=64)$ considered learning mathematics among the three most important characteristics of a successful PBL unit. Other options that they considered as most important for a successful PBL unit in mathematics were all related to student motivation and learning of twenty-first century skills. In line with this, the results indicate a need to emphasise the importance of planning the PBL unit around the core curriculum so that in-depth subject teaching can occur (Grossman et al., 2019; Tal et al., 2006). Context-based and problem-based approaches to instruction are seen as useful for student learning in biology (Cabbar \& Senel, 2020; Jeronen et al., 2017), but if the focus is not on central concepts, then it remains uncertain how useful the PBL units are from the perspective of academic performance.

Development of twenty-first century skills is vital for solving issues related to sustainability, which makes PBL an attractive approach for teaching topics related to it (Konrad et al., 2020). Using environmental issues as the starting point of PBL projects in science education has become increasingly popular, and there is a growing body of evidence of its usefulness as a way to implement STEM PBL (for example, Hugerat, 2020; Triana et al., 2020; Kricsfalusy et al., 2018). This study is in line with that as students stated that their environmental attitudes had developed in several schools $(n=4)$. Teachers mentioned developing students' environmental values as learning goals of the projects in $n=5$ schools, and $n=2$ schools mentioned that the goal had been reached. However, as the participants of this study had a lot of freedom in terms of what they decided to report about their projects, teachers not explicitly mentioning the development of environmental values does not necessarily mean that the goal was not reached.

\section{Limitations}

Content analysis can only focus on what is visible in the materials (Cohen et al., 2007). As teachers and students have reported their project work to the StarT competition that searches good models for the implementation of PBL, it can be expected that the teachers would 
highlight (and instruct their students to highlight) the aspects of PBL that they consider important in the videos and written descriptions that they provided. Consequently, if a certain characteristic of PBL is not visible in their materials at all, it is likely that teachers are either not aware of it or do not consider it that important for the implementation of PBL. However, as participating in competitions such as StarT is usually extra work for the teachers, they might struggle to find the time to provide materials that accurately represent their views on what was essential for the project. Furthermore, the form of reporting was very open-ended (for example, videos and learning diaries). As such, it remains possible that if the instructions for reporting the PBL unit had included specific questions about certain characteristics, teachers might have been able to comment on them. Nevertheless, it remains true that in their reports, teachers would include what they valued and focused on most in their projects.

What is more, as participation in StarT is completely voluntary, it is likely that the sample of teachers and schools studied is limited to those that are already actively interested and implementing PBL. As such, the results cannot necessarily be expected to represent PBL that is carried out in an average classroom; the focus is clearly on teachers who are already actively engaged in PBL and science education programmes. As one would expect, PBL implementation can be greatly influenced by school context and whether it is supported by school leadership or not (Condliffe et al., 2017).

A further limitation to the results is the scope of the materials and the limitations they had for determining the extent of student-centredness in projects; only inferences can be ascertained about which decisions were made by the students and which by the teachers. However, the interpretations that were made during the coding process have been carefully described in 'Methods'. As such, whilst the materials limited the deductions that could be made confidently, the analysis is reliable within said limitations.

The number of separate schools in this study is 12 . However, three of them did interact with each other as they participated in the same development programme organised by a local university. Nevertheless, as Stake (2000) states, the main aim of a case study is not to generalise results but to understand the cases better. The aim of the study is not to claim that the results would be true to all teachers but to gain more understanding of how individual teachers might see PBL and find trends across individual cases.

\section{Conclusion}

This study supports the notion that teachers have varying conceptions of PBL and its characteristics (Hasni et al., 2016). The study provided new information of PBL that takes place at schools that are active participants in international education competitions, as they have not been researched from the perspective of the characteristics of PBL earlier. As such, it also shows how teachers who are actively engaged in PBL implement the characteristics, therefore giving an idea of what the 'best-case scenario' of the implementation of PBL units that are not guided by researchers might be. Additionally, due to the international sample of schools studied, the study is not limited to a specific educational context.

This study provides important information for teacher training, as it has paved the way into studying the quality of PBL units created by teachers as opposed to those created by researchers through the lens of key characteristics of PBL. Based on the results, the authors believe it is important to ensure that teacher training and curriculum development consider how teachers can use PBL to teach central content, and how schools can better support teachers to carry this out in terms of resources and time.

In line with Morrison et al. (2020) and Tsybulsky \& Muchnik-Rozanov (2019), the authors believe it would be important for teachers themselves to learn through PBL during their pre-service training. Furthermore, for teachers to be able to fully grasp the pedagogical approach required in $\mathrm{PBL}$, both teacher training and research should consider the key characteristics and their implementation, especially those that have been shown to cause more difficulties for teachers through this and earlier studies (for example, teaching central content, students' questions and driving questions). Additionally, it may be useful to direct efforts into studying the key characteristics from the perspective of flexible implementation; which of the characteristics should be followed rigidly, and could some of them be interpreted more flexibly to suit local educational contexts better? For example, considering the importance placed on the driving question in PBL literature, and the difficulties in its implementation, it would be useful to understand how the characteristic could be contextualised into a format that is more easily accessible to teachers.

Finally, a viable framework was created for analysing how the key characteristics of PBL were implemented in teachers' projects. It can be adapted for studying PBL units also in other settings. The used approach to analysing project units can also be used as a starting point for studying PBL artefacts, which has been advocated for by Guo et al. (2020) and Hasni et al. (2016). What is more, it allows studying PBL from the point of view of students, which has also been done clearly less in PBL research (Habók \& Nagy, 2016).

The authors believe that research should continue to address PBL units from the perspective of the key characteristics of PBL. This allows research to be grounded in the practice of schools, and for 
researchers to pinpoint the most critical aspects of PBL that professional development initiatives should focus on. PBL remains a challenging instructional method and a lot more training and resources are still needed for it to live up to its potential. The results from this study and the constructed framework of key characteristics can be useful in promoting research-based implementation and design of PBL science education, and in teacher training related to it.

\section{Abbreviations}

PBL: Project-based learning; STEM: Science, technology, engineering and mathematics.

\section{Authors' contributions}

The study was designed by AM, with comments from MA. AM designed the framework used in the analysis and carried out the data collection and analysis. AM was responsible for writing the manuscript, with contributions and comments from MA. All authors read and approved the final manuscript.

\section{Funding}

LUMA resources Ms Anette Markula MSC

\section{Declaration}

\section{Competing interests}

The authors declare that they have no competing interests.

Received: 31 October 2020 Accepted: 2 December 2021

Published online: 06 January 2022

\section{References}

Abd-El-Khalick, F., Boujaoude, S., Duschl, R., Lederman, N. G., Mamlok-Naaman, R., Hofstein, A., \& Tuan, H. L. (2004). Inquiry in science education: International perspectives. Science education, 88(3), 397-419. https://doi.org/10.1002/sce.1 0118 Aksela M. K. \& Haatainen, O. M. (2019). Project-Based Learning (PBL) in Practise: Active Teachers' Views of Its' Advantages And Challenges. Integrated Education for the Real World: 5th International STEM in Education Conference Post-Conference Proceedings, The Queensland University of Technology, 9-16.

Aksela, M., \& Haatainen, O. (2019). Project-based learning (PBL) in practise: Active Teachers' Views of Its Advantages and Challenges. In Integrated Education for the Real World: 5th International STEM in Education Conference PostConference Proceedings (pp. 9-16). Queensland University of Technology.

Annetta, L. A., Lamb, R., \& Vallett D.\& Shapiro M. (2019). In Project-based learning progressions: Identifying the nodes of learning in a project-based environment, O. Adesope, \& A. Rud (Eds.), Contemporary Technologies in Education, (pp. 163-181). Cham: Palgrave Macmillan. https://doi.org/10.1007/ 978-3-319-89680-9_9.

Balemen, N., \& Özer Keskin, M. (2018). The effectiveness of project-based learning on science education: A meta-analysis search. International Online Journal of Education and Teaching (IOJET), 5(4), 849-865 http://iojet.org/index.php/ IOJET/article/view/452/297.

Baxter, P., \& Jack, S. (2008). Qualitative case study methodology: Study design and implementation for novice researchers. The Qualitative Report, 13(4), 544559 .

Bell, S. (2010). Project-based learning for the 21st century: Skills for the future. The Clearing House, 83(2), 39-43. https://doi.org/10.1080/00098650903505415.

Bestelmeyer, S. V., Elser, M. M., Spellman, K. V., Sparrow, E. B., Haan-Amato, S. S., \& Keener, A. (2015). Collaboration, interdisciplinary thinking, and communication: New approaches to K-12 ecology education. Frontiers in Ecology and the Environment, 13(1), 37-43. https://doi.org/10.1890/140130

Blumenfeld, P. C., Soloway, E., Marx, R. W., Krajcik, J. S., Guzdial, M., \& Palincsar, A. (1991). Motivating project-based learning: Sustaining the doing, supporting the learning. Educational Psychologist, 26(3-4), 369-398. https://doi.org/10.1 080/00461520.1991.9653139

Cabbar, B. G., \& Senel, H. (2020). Content analysis of biology education research that used context-based approaches: The case of Turkey. Journal of Educational Issues, 6(1), 203-218. https://doi.org/10.5296/jei.v6i1.16920.
Capraro, R. M., Capraro, M. M., Scheurich, J. J., Jones, M., Morgan, J., Huggins, K. S., ... Han, S. (2016). Impact of sustained professional development in STEM on outcome measures in a diverse urban district. The Journal of Educational Research, 109(2), 181-196. https://doi.org/10.1080/00220671.2014.936997.

Chen, C. H., \& Yang, Y. C. (2019). Revisiting the effects of project-based learning on students' academic achievement: A meta-analysis investigating moderators. Educational Research Review, 26, 71-81. https://doi.org/10.1016/j. edurev.2018.11.001.

Chin, C., \& Osborne, J. (2008). Students' questions: A potential resource for teaching and learning science. Studies in Science Education, 44(1), 1-39. https://doi.org/10.1080/03057260701828101.

Cohen, L., Manion, L., \& Morrison, K. (2007). Research methods in education, (6th ed., ). London: Taylor \& Francis. https://doi.org/10.4324/9780203029053.

Colley, K. E. (2006). Understanding ecology content knowledge and acquiring science process skills through project-based science instruction. Science Activities: Classroom Projects and Curriculum Ideas, 43(1), 26-33. https://doi. org/10.3200/SATS.43.1.26-33.

Condliffe, B., Quint, J., Visher, M. G., Bangser, M. R., Drohojowska, S., Saco, L., \& Nelson, E. (2017). Project-based learning: A literature review. MDRC: Working Paper https://www.mdrc.org/publication/project-based-learning. Accessed 31 May 2021.

Edelson, D. C. (2001). Learning-for-use: A framework for the design of technology-supported inquiry activities. Journal of Research in Science Teaching, 38(3), 355-385. https://doi.org/10.1002/1098-2736(200103)38:33.0. $\mathrm{CO} ; 2-\mathrm{M}$.

Elo, S., Kääriäinen, M., Kanste, O., Pölkki, T., Utriainen, K., \& Kyngäs, H. (2014). Qualitative content analysis: A focus on trustworthiness. SAGE Open, 4(1). https://doi.org/10.1177/2158244014522633.

Erdoğan, N., Navruz, B., Younes, R., \& Capraro, R. M. (2016). Viewing how STEM project-based learning influences students' science achievement through the implementation lens: A latent growth modeling. Eurasia Journal of Mathematics, Science \& Technology Education, 12(8), 2139-2154. https://doi. org/10.12973/eurasia.2016.1294a.

European Commission. (2007). Science education NOW: A renewed pedagogy for the future of Europe. Available https://ec.europa.eu/research/swafs/index. cfm?pg=library\&lib=science_edu. Accessed 1 May 2020.

Grossman, P., Dean, C. G. P., Kavanagh, S. S., \& Herrmann, Z. (2019). Preparing teachers for project-based teaching. Phi Delta Kappan, 100(7), 43-48. https:// doi.org/10.1177/0031721719841338.

Guo, P., Saab, N., Post, L. S., \& Admiraal, W. (2020). A review of project-based learning in higher education: Student outcomes and measures. International Journal of Educational Research, 102, 101586. https://doi.org/10.1016/j.jier.202 0.10158Gustafsson J. (2017). Single case studies vs. multiple case studies: A comparative study. Available: https://www.diva-portal.org/smash/get/diva2:1 064378/FULLTEXT01.pdf Accessed 1 October 2020.

Haatainen, O., \& Aksela, M. (2021). Project-based learning in integrated science education: Active teachers' perceptions and practices. LUMAT: International Journal on Math, Science and Technology Education, 9(1), 149-173. https://doi. org/10.31129/LUMAT.9.1.1392.

Habók, A., \& Nagy, J. (2016). In-service teachers' perceptions of project-based learning. SpringerPlus, 5(1), 83. https://doi.org/10.1186/s40064-016-1725-4.

Han, S., Yalvac, B., Capraro, M. M., \& Capraro, R. M. (2015). In-service teachers' implementation and understanding of STEM project-based learning, EURASIA Journal of Mathematics, Science \& Technology Education, 11(1), 63-76. https://doi.org/10.12973/eurasia.2015.1306a.

Hasni, A., Bousadra, F., Belletête, V., Benabdallah, A., Nicole, M., \& Dumais, N. (2016). Trends in research on project-based science and technology teaching and learning at K-12 levels: A systematic review. Studies in Science Education, 52(2), 199-231. https://doi.org/10.1080/03057267.2016.1226573.

Herranen, J., \& Aksela, M. (2019). Student-question-based inquiry in science education. Studies in Science Education, 55(1), 1-36. https://doi.org/10.1080/03 057267.2019.1658059.

Hmelo-Silver, C. (2004). Problem-based learning: What and how do students learn? Educational Psychology Review, 16(3), 235-266. https://doi.org/10.1023/ B:EDPR.0000034022.16470.f3.

Hsieh, H. F., \& Shannon, S. E. (2005). Three approaches to qualitative content analysis. Qualitative Health Research, 15(9), 1277-1288. https:/doi.org/10.11 77/1049732305276687.

Hugerat, M. (2020). Incorporating sustainability into chemistry education by teaching through project-based learning. In chemistry education for a sustainable society volume 1: High school, outreach, \& global perspectives. 
American Chemical Society, 79-96. https://doi.org/10.1021/bk-2020-1344. ch007.

Jeronen, E., Palmberg, I., \& Yli-Panula, E. (2017). Teaching methods in biology education and sustainability education including outdoor education for promoting sustainability - A literature review. Education Sciences, 7(1), 1. https://doi.org/10.3390/educsci7010001.

Kaldi, S., Filippatou, D., \& Govaris, C. (2011). Project-based learning in primary schools: Effects on pupils' learning and attitudes. Education 3-13, 39(1), 3547. https://doi.org/10.1080/03004270903179538.

Konrad, T., Wiek, A., \& Barth, M. (2020). Embracing conflicts for interpersonal competence development in project-based sustainability courses. International Journal of Sustainability in Higher Education, 21(1), 76-96. https:// doi.org/10.1108/IJSHE-06-2019-0190.

Kortam, N., Basheer, A., Hofstein, A., \& Hugerat, M. (2018). How project-based learning promotes 7 th grade students' motivation and attitudes towards studying biology. Action Research and Innovation in Science Education, 1(2), 9-17. https://doi.org/10.12973/arise/103043.

Krajcik, J. (2015). Project-based science. The Science Teacher, 82(1), 25-27. https:// doi.org/10.2505/4/tst15_082_01_25.

Krajcik, J. S., \& Shin, N. (2014). In Project-based learning, \& R. K. Sawyer (Eds.), The Cambridge handbook of the learning sciences, (2nd ed., pp. 275-297). Cambridge: Cambridge University Press. https://doi.org/10.1017/CBO978113 9519526.018.

Kricsfalusy, V., George, C., \& Reed, M. G. (2018). Integrating problem-and projectbased learning opportunities: Assessing outcomes of a field course in environment and sustainability. Environmental Education Research, 24(4), 593610. https://doi.org/10.1080/13504622.2016.1269874.

Lähdemäki, J. (2019). In Case study: The Finnish National Curriculum 2016-A cocreated National Education Policy, \& J. Cook (Eds.), Sustainability, human wellbeing, and the future of education. Cham: Palgrave Macmillan. https://doi. org/10.1007/978-3-319-78580-6_13.

Lattimer, H., \& Riordan, R. (2011). Project-based learning engages students in meaningful work. Middle School Journal, 43(2), 18-23. https://doi.org/10.1080/ 00940771.2011 .11461797$.

Lavonen, J., Inkinen, J., Juuti, K., Salmela-Aro, K., Krajcik, J., \& Schneider, B. (2017). In The influence of an international professional development project for the design of engaging secondary science teaching in Finland, M. K. Mhlolo, S. N. Matoti, \& B. Fredericks (Eds.), Book of long papers: 25th annual meeting of the southern African Association of Researchers in Mathematics Science \& Technology Education (SAARMSTE), (pp. 206-220) SAARMSTE.

Malone, T. W., \& Lepper, M. R. (1987). In ). Making learning fun: A taxonomy of intrinsic motivations for learning, R. Snow, \& M. Farr (Eds.), Aptitude, learning, and instruction: Conative and affective process analyses, (pp. 223-253). Hillsdale, NJ: Lawrence Erlbaum Associates, Inc..

Marshall, C., \& Rossman, G. B. (2014). Designing qualitative research, (6th ed., ). Inc: SAGE Publications.

Mentzer, G. A., Czerniak, C. M., \& Lisa, B. (2017). An examination of teacher understanding of project-based science as a result of participating in an extended professional development program: Implications for implementation. School Science and Mathematics, 117(1-2), 76-86. https://doi. org/10.1111/ssm.12208

Miller, E. C., \& Krajcik, J. S. (2019). Promoting deep learning through project-based learning: A design problem. Disciplinary and Interdisciplinary Science Education Research, 1(1), 1-10. https://doi.org/10.1186/s43031-019-0009-6.

Morrison, J., Frost, J., Gotch, C., McDuffie, A. R., Austin, B., \& French, B. (2020). Teachers' role in students' learning at a project-based STEM high school: Implications for teacher education. International Journal of Science and Mathematics Education, 1-21. https://doi.org/10.1007/s10763-020-10108-3.

National Academy of Engineering \& National Research Council. (2014). STEM integration in K-12 education: Status, prospects, and an agenda for research. Washington, DC: The National Academies Press. Available https://www.nap. edu/catalog/18612/stem-integration-in-k-12-education-status-prospects-and-a n. Accessed 1 of May 2020.

National Research Council. (2012). A framework for K-12 science education: Practices, crosscutting concepts, and core ideas. Washington, DC: The National Academies Press. Available https://www.nap.edu/catalog/13165/a-fra mework-for-k-12-science-education-practices-crosscutting-concepts. Accessed 1 May 2020.

Novak, A. M., \& Krajcik, J. S. (2020). In M. Moallem, W. Hung, \& N. Dabbagh (Eds.), A case study of project-based learning of middle school students exploring water quality, (pp. 551-527). The Wiley handbook of problem-based learning. https://doi.org/10.1002/9781119173243.ch24.

Pan, G., Seow, P. S., Shankararaman, V., \& Koh, K. (2020). An exploration into key roles in making project-based learning happen: Insights from a case study of a university. Journal of International Education in Business, 14(1), 109-129. https://doi.org/10.2139/ssin.3603881.

Parker, W. C., Lo, J., Yeo, A. J., Valencia, S. W., Nguyen, D., Abbott, R. D., ... Vye, N. J. (2013). Beyond breadth-speed-test: Toward deeper knowing and engagement in an advanced placement course. American Educational Research Journal, 50(6), 1424-1459. https://doi.org/10.3102/0002831213504237.

Pedaste, M., Mäeots, M., Siiman, L. A., De Jong, T., Van Riesen, S. A., Kamp, E. T., .. Tsourlidaki, E. (2015). Phases of inquiry-based learning: Definitions and the inquiry cycle. Educational Research Review, 14, 47-61. https://doi.org/10.1016/ j.edurev.2015.02.003.

Sadler, T. D. (2009). Situated learning in science education: Socio-scientific issues as contexts for practice. Studies in Science Education, 45(1), 1-42. https://doi. org/10.1080/03057260802681839.

Sahin, A. (2013). In STEM project-based learning, R. M. Capraro, M. M. Capraro, \& J. R. Morgan (Eds.), STEM project-based learning (2nd volume, p. 59-64). Rotterdam: SensePublishers. https://doi.org/10.1007/978-94-6209-143-6_7.

Sasson, I., Yehuda, I., \& Malkinson, N. (2018). Fostering the skills of critical thinking and question-posing in a project-based learning environment. Thinking Skills and Creativity, 29, 203-212. https://doi.org/10.1016/j.tsc.2018.08.001.

Severance, S., \& Krajcik, J. (2018). In Examining primary teacher expertise and Agency in the Collaborative Design of project-based learning innovations, J. Kay, \& R. Luckin (Eds.), Rethinking learning in the digital age: Making the learning sciences count, 13th international conference of the learning sciences (ICLS) 2018, volume 2. International Society of the Learning Sciences: London, UK.

Stake, R. E. (2000). Case studies. In N. K. Denzin, \& Y. S. Lincoln (Eds.), Handbook of qualitative research, (2nd ed., pp. 236-247). Thousand Oaks: Sage Publications.

StarT programme. The International StarT Competition. https://start.luma.fi/en/sta rt-competition/. Accessed 15 Apr 2020

Stearns, L. M., Morgan, J., Capraro, M. M., \& Capraro, R. M. (2012). A teacher observation instrument for PBL classroom instruction. Journal of STEM Education: Innovations and Research, 13(3), 7-16.

Tal, T., Krajcik, J. S., \& Blumenfeld, P. C. (2006). Urban schools' teachers enacting project-based science. Journal of Research in Science Teaching, 43(7), 722-745. https://doi.org/10.1002/tea.20102.

Tamim, S. R., \& Grant, M. M. (2013). Definitions and uses: Case study of teachers implementing project-based learning. Interdisciplinary Journal of ProblemBased Learning, 7(2), 72-101. https://doi.org/10.7771/1541-5015.1323.

Thomas, J. W. (2000). A review of research on project-based learning. San Rafael, CA: Autodesk Foundation Available http://www.bie.org/object/document/a_ review_of_research_on_project_based_learning. Accessed 30 August 2019.

Thys, M., Verschaffel, L., Van Dooren, W., \& Laevers, F. (2016). Investigating the quality of project-based science and technology learning environments in elementary school: A critical review of instruments. Studies in Science Education, 52(1), 1-27. https://doi.org/10.1080/03057267.2015.1078575.

Triana, D., Anggraito, Y. U., \& Ridlo, S. (2020). Effectiveness of environmental change learning tools based on STEM-PjBL towards 4 C skills of students. Journal of Innovative Science Education, 9(2), 181-187. https://doi.org/10.152 94/JISE.V8|3.34048.

Tsybulsky, D., \& Muchnik-Rozanov, Y. (2019). The development of studentteachers' professional identity while team-teaching science classes using a project-based learning approach: A multi-level analysis. Teaching and Teacher Education, 79, 48-59. https://doi.org/10.1016/j.tate.2018.12.006.

Turner, S. F., Cardinal, L. B., \& Burton, R. M. (2017). Research Design for Mixed Methods: A triangulation-based framework and roadmap. Organizational Research Methods, 20(2), 243-267. https://doi.org/10.1177/1094428115610808.

Viro, E., Lehtonen, D., Joutsenlahti, J., \& Tahvanainen, V. (2020). Teachers' perspectives on project-based learning in mathematics and science. European Journal of Science and Mathematics Education, 8(1), 12-31. https:// doi.org/10.30935/scimath/9544.

Yin, R. K. (2014). Case study research: Design and methods, (5th ed., ). Inc: SAGE Publications.

\section{Publisher's Note}

Springer Nature remains neutral with regard to jurisdictional claims in published maps and institutional affiliations. 